\title{
Diclofenac Abatement using Modified Solar Photo-Fenton Process with Ammonium Iron(III) Citrate
}

\author{
Alam G. Trovó ${ }^{\#}$ and Raquel F. P. Nogueira* \\ Instituto de Química de Araraquara, Universidade Estadual Paulista, \\ CP 355, 14801-970 Araraquara-SP, Brazil
}

\begin{abstract}
A influência do pH na degradação do fármaco diclofenaco (DCF) por processo foto-Fenton/ solar foi avaliada usando o complexo citrato de amônio e ferro(III) $\left(\mathrm{FecitNH}_{4}\right)$. Embora a eficiência de degradação diminua com o aumento do $\mathrm{pH}$ (no intervalo de $\mathrm{pH}$ de 5 a 8), a concentração de DCF ficou abaixo do limite de detecção após 45 min de irradiação enquanto que $77 \%$ do carbono orgânico total foi removido após $150 \mathrm{~min}$ em pH 7 (sem ajuste posterior). Foi verificada cinética de primeira ordem para a degradação de DCF, cuja constante de velocidade aumentou com o aumento das concentrações de Fecit $\mathrm{NH}_{4} \mathrm{e}_{2} \mathrm{O}_{2}$. Menor degradação de DCF foi observada quando presente na matriz efluente de estação de tratamento de esgoto (ETE), devido principalmente à alta concentração de carbonato e bicarbonato em pH 7. Entretanto, após ajuste de pH para 5, a concentração de DCF ficou abaixo do limite de detecção após 75 min de irradiação.
\end{abstract}

The influence of $\mathrm{pH}$ on the degradation of the pharmaceutical diclofenac (DCF) by the solar/ photo-Fenton process was investigated using ammonium iron(III) citrate complex $\left(\mathrm{FecitNH}_{4}\right)$. Although the degradation efficiency decreased as the $\mathrm{pH}$ increased (in the $\mathrm{pH}$ range 5 to 8), the DCF concentration was lower than its limit of detection after 45 min irradiation while $77 \%$ of the total organic carbon was removed after 150 min irradiation at initial $\mathrm{pH} 7$ (without further adjustment). A pseudo-first-order kinetics of DCF degradation was observed, which kinetic constant increased with the increase of the concentrations of FecitNH $\mathrm{H}_{4}$ and $\mathrm{H}_{2} \mathrm{O}_{2}$. Lower DCF degradation was observed when present in a sewage treatment plant (STP) effluent sample, mainly due to the high concentration of carbonate and bicarbonate at $\mathrm{pH} 7$. However, after adjusting the $\mathrm{pH}$ to 5, the DCF concentration was lower than its detection limit after 75 min irradiation.

Keywords: pharmaceutical, wastewater, advanced oxidation process, iron complex

\section{Introduction}

The human consumption of pharmaceuticals as well as veterinary practices and industrial activities including aquaculture has lead to contamination of surface and groundwater. The incomplete removal of these compounds during conventional sewage treatment contributes to contamination by pharmaceuticals what is of great environmental concern in recent years. ${ }^{1-3}$ Different classes of pharmaceuticals, such as antibiotics, hormones, anaesthetics and anti-inflammatories, have been detected at average concentrations ranging from $\mathrm{ng} \mathrm{\textrm {L } ^ { - 1 }}$ to $\mu \mathrm{g} \mathrm{L}^{-1}$ in sewage treatment plant (STP) effluents, as well as in surface and

*e-mail: nogueira@iq.unesp.br

\#Present address: Instituto de Química, Universidade Federal de Uberlândia, CP 593, 38400-902 Uberlândia-MG, Brazil groundwater. ${ }^{4-11}$ These contaminants do not need to persist in the environment to cause a negative effect, since their high transformation/removal rates can be compensated by their continuous introduction into the environment. Among the pharmaceuticals, the anti-inflammatory diclofenac (DCF) has been found in most STP effluents due the its low biodegradability during conventional sewage treatment (ranging from 9 to $60 \%$ ). ${ }^{8,11}$ Therefore, it is important to evaluate new procedures designed to prevent water contamination, considering the risks that residual pharmaceuticals can present to human health and to the environment. ${ }^{12}$ The application of advanced oxidation processes (AOPs), based on the generation of highly oxidizing hydroxyl radicals $\left({ }^{\circ} \mathrm{OH}\right)$, can be a good alternative, due to their simplicity and the possibility of using sunlight, as in the photo-Fenton process and heterogeneous photocatalysis, which reduces energy costs. ${ }^{13-15}$ 
Reports of the direct photolysis of DCF in lake and pure water under sunlight and UV irradiation, as well as its degradation using different oxidation processes such as $\mathrm{H}_{2} \mathrm{O}_{2} / \mathrm{UV}$ and ozonation, are indicative of significant dechlorination and mineralization..$^{16-19}$ Degradation using the photo-Fenton process has been demonstrated to be more efficient than heterogeneous photocatalysis, achieving total oxidation of DCF in half the time..$^{20}$ However, during the photo-Fenton treatment it was observed that DCF precipitates at $\mathrm{pH}$ below 4 $\left(\mathrm{pK}_{\mathrm{a}}=4.15\right.$ ), and high $\mathrm{H}_{2} \mathrm{O}_{2}$ concentrations (between 1360 and $3740 \mathrm{mg} \mathrm{L}^{-1}$ ) were necessary for complete DCF degradation.

Considering the optimum $\mathrm{pH}$ range (2.5-3.0) for the Fenton reaction, the use of iron complexes is a promising alternative for DCF degradation at circumneutral $\mathrm{pH}$, since in the presence of organic ligands the iron can be maintained soluble over a wider $\mathrm{pH}$ range.

Another advantage of using iron complexes is their high absorption in the UV-Vis region, which allows use of a considerable portion of the solar spectrum, reducing the operating costs. In addition, degradation efficiency is usually higher in the presence of iron complexes, compared to iron salts. ${ }^{21}$ The high quantum yield of Fe(II) generation has been highlighted as one of the main reasons for the high efficiency of iron(III) complexes with citrate, oxalate and other carboxylates.

Various chelating agents have been evaluated for activation of hydrogen peroxide at circumneutral $\mathrm{pH} .{ }^{22}$ However, the harmful effects of some chelating agents, such as ethylenediaminetetraacetic acid and nitrilotriacetic acid, have recently been acknowledged, and their use in environmental applications has been avoided. In contrast, citrate is a representative natural organic chelating agent that is environmentally friendly since it is readily biodegradable. ${ }^{23}$

The use in the photo-Fenton process of ferric citrate complex, prepared in situ through the addition of citrate to iron salts, has previously been shown to be viable at higher pH values. ${ }^{24-28}$ In the present work, the commercial ammonium iron(III) citrate complex $\left(\mathrm{FecitNH}_{4}\right)$ was employed.

Therefore the goal of the present work was to evaluate the DCF degradation by the photo-Fenton process using $\mathrm{FecitNH}_{4}$. The effect of $\mathrm{pH}$, as well as the influence of iron and $\mathrm{H}_{2} \mathrm{O}_{2}$ concentrations was evaluated. Considering that DCF is often present in STP effluents, its degradation was also evaluated in this matrix to verify to which extent the effluent constituents might affect the efficiency of the photo-Fenton process.

\section{Experimental}

\section{Reagents}

Potassium diclofenac (All Chemistry) was used as received for solution preparation. Sodium diclofenac standard (Sigma-Aldrich) was used to construct calibration curves for quantification. $\mathrm{H}_{2} \mathrm{O}_{2}(30 \% \mathrm{~m} / \mathrm{m})$ (Synth), ammonium iron(III) citrate complex (Vetec), $\mathrm{H}_{2} \mathrm{SO}_{4}$ and $\mathrm{NaOH}$ (Synth), and bovine liver catalase (Sigma-Aldrich) were used as received. Ammonium metavanadate (Vetec) solution was prepared at a concentration of $0.06 \mathrm{~mol} \mathrm{~L}^{-1}$ in $0.58 \mathrm{~mol} \mathrm{~L}^{-1} \mathrm{H}_{2} \mathrm{SO}_{4}$. $\mathrm{KH}_{2} \mathrm{PO}_{4}$ (Mallinckrodt) and $\mathrm{H}_{3} \mathrm{PO}_{4}$ (Synth) were also used as received. All reagents were analytical grade. All solutions were prepared using distilled water (DW), except in experiments using STP effluent. Methanol for high performance liquid chromatography (HPLC grade) was used in HPLC analysis.

\section{Sewage treatment plant effluent}

In order to evaluate matrix effects on DCF degradation, a sample of effluent was collected from a STP employing activated sludge treatment and serving the population of almost 200,000 inhabitants of the city of Araraquara, Brazil. The sample was collected after complete treatment and kept refrigerated, for a maximum of one week, until the experiments were performed. The main parameters determined for the sample are shown in Table 1. The samples were spiked with DCF and filtered through $0.45 \mu \mathrm{m}$ membranes before chemical analysis.

Table 1. Main parameters determined for the sample of STP effluent

\begin{tabular}{|c|c|}
\hline Parameters & STP effluent \\
\hline Dissolved organic carbon / $\left(\mathrm{mg} \mathrm{C} \mathrm{L}^{-1}\right)^{\mathrm{a}}$ & 18 \\
\hline Dissolved inorganic carbon / $\left(\mathrm{mg} \mathrm{C} \mathrm{L}^{-1}\right)^{\mathrm{a}}$ & 60 \\
\hline $\mathrm{pH}^{\mathrm{b}}$ & 7 \\
\hline Turbidity / (nephelometric units) ${ }^{b}$ & 275 \\
\hline $\mathrm{BOD} /\left(\mathrm{mg} \mathrm{O}_{2} \mathrm{~L}^{-1}\right)^{\mathrm{b}}$ & 66 \\
\hline $\mathrm{COD} /\left(\mathrm{mg} \mathrm{O}_{2} \mathrm{~L}^{-1}\right)^{\mathrm{b}}$ & 265 \\
\hline Dissolved $\mathrm{O}_{2} /\left(\mathrm{mg} \mathrm{L}^{-1}\right)^{\mathrm{b}}$ & 2.1 \\
\hline Total chloride / $\left(\mathrm{mg} \mathrm{L}^{-1}\right)^{\mathrm{b}}$ & 57.7 \\
\hline Dissolved Fe / $\left(\mathrm{mg} \mathrm{L}^{-1}\right)^{\mathrm{b}}$ & 0.25 \\
\hline Nitrate / $\left(\mathrm{mg} \mathrm{L}^{-1}\right)^{\mathrm{b}}$ & 0.42 \\
\hline Total nitrogen $($ Kjedahl $) /\left(\mathrm{mg} \mathrm{L}^{-1}\right)^{\mathrm{b}}$ & 39.2 \\
\hline Total solids / $\left(\mathrm{mg} \mathrm{L}^{-1}\right)^{\mathrm{b}}$ & 717 \\
\hline Total dissolved solids / $\left(\mathrm{mg} \mathrm{L}^{-1}\right)^{\mathrm{b}}$ & 571 \\
\hline Total suspension solids / $\left(\mathrm{mg} \mathrm{L}^{-1}\right)^{\mathrm{b}}$ & 146 \\
\hline
\end{tabular}

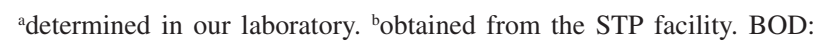
biological oxygen demand; COD: chemical oxygen demand.

\section{Photodegradation procedure}

The photodegradation experiments were carried out in Araraquara, Brazil $\left(22^{\circ} \mathrm{S} 48^{\circ} \mathrm{W}\right)$, using a solar reactor composed of a $49.5 \mathrm{~cm}$ long glass tube with an internal 
diameter of $3.6 \mathrm{~cm}$, previously described by Trovó et al. ${ }^{14}$ The experiments were performed during winter, between 10 am and $2 \mathrm{pm}$.

All experiments were carried out at an initial DCF concentration of $33.4 \mathrm{mg} \mathrm{L}^{-1}\left(0.1 \mathrm{mmol} \mathrm{L} \mathrm{L}^{-1}\right.$ potassium diclofenac, $16.8 \mathrm{mg}$ of $\mathrm{C}$ per $\mathrm{L}$ of total organic carbon). Although this concentration is far above the expected levels in the environment, this concentration was chosen due to the difficulty in working at trace levels with HPLC and to permit DCF quantification during irradiation since the detection and quantification limits determined were 0.14 and $0.46 \mathrm{mg} \mathrm{L}^{-1}$, respectively. Taking into consideration the maximum concentration of iron allowed in wastewater according to Brazilian legislation $\left(15 \mathrm{mg} \mathrm{L}^{-1}\right.$ or $\left.0.27 \mathrm{mmol} \mathrm{L}^{-1}\right)$, the experiments were performed at three different initial concentrations of ammonium iron (III) citrate $\left(\mathrm{FecitNH}_{4}\right)\left(0.05,0.1\right.$ and $\left.0.2 \mathrm{mmol} \mathrm{L}^{-1}\right)$, which are below this limit. Based on previous work, the initial $\mathrm{H}_{2} \mathrm{O}_{2}$ concentration studied ranged from 34 to $170 \mathrm{mg} \mathrm{L}^{-1} .{ }^{15}$ For DCF kinetics evaluation in DW and STP effluent, $68 \mathrm{mg} \mathrm{L}^{-1}$ $\mathrm{H}_{2} \mathrm{O}_{2}$ were added at the beginning of the reaction, with new additions of $\mathrm{H}_{2} \mathrm{O}_{2}$ during the experiments, according to the consumption of $\mathrm{H}_{2} \mathrm{O}_{2}$. The initial $\mathrm{pH}$ value of each solution was adjusted to the desired value within the range 5-8 without a buffer solution, by adding $\mathrm{H}_{2} \mathrm{SO}_{4}$ or $\mathrm{NaOH} \cdot{ }^{27}$

The irradiated volume of the reactor was $510 \mathrm{~mL}$, and a total volume of $800 \mathrm{~mL}$ of the pharmaceutical solution was recirculated at a flow rate of $80 \mathrm{~mL} \mathrm{~min}^{-1}$, using a peristaltic pump (Masterflex 7518-12), after the addition of FecitNH $\mathrm{H}_{4}$ complex solution, adjustment of the $\mathrm{pH}$ and addition of $\mathrm{H}_{2} \mathrm{O}_{2}$. The reactor remained covered while the glass tube was being filled. Once the tube was completely filled, it was exposed to the sunlight. The solar energy dose accumulated during the exposure time, and the average irradiance, were measured using a radiometer (PMA 2100 Solar Light Co.) in the UVA region ( $320-400 \mathrm{~nm})$, with the sensor placed at the same angle as that of the reactor. The average solar irradiance measured during the experiments was $14.8 \pm 1.2 \mathrm{~W} \mathrm{~m}^{-2}$.

\section{Chemical analysis}

Before HPLC analysis, the solution $\mathrm{pH}$ was adjusted to between 6 and 8 , and $250 \mu \mathrm{L}$ of catalase solution $\left(0.1 \mathrm{~g} \mathrm{~L}^{-1}\right)$ was added to $10 \mathrm{~mL}$ of sample to consume residual hydrogen peroxide and consequently interrupt the degradation reaction. During irradiation the concentration of DCF was determined, after filtration through $0.45 \mu \mathrm{m}$ membranes, by HPLC analysis using a Shimadzu LC10 AVP coupled to a diode array detector (SPD-M10A) and a Phenomenex reversed phase Luna C18 column $(250 \mathrm{~mm} \times 4.6 \mathrm{~mm}$,
$5 \mu \mathrm{m})$. The mobile phase used as eluent consisted of a binary mixture of $25 \mathrm{mmol} \mathrm{L}^{-1} \mathrm{KH}_{2} \mathrm{PO}_{4}$ buffer ( $\mathrm{pH} 3.5$ ) and methanol (30:70), at a flow rate of $1 \mathrm{~mL} \mathrm{~min}^{-1}$. The injection volume was $20 \mu \mathrm{L}$ and the column temperature $40{ }^{\circ} \mathrm{C}$. Under these conditions, the retention time of DCF was $10.8 \mathrm{~min}$.

Mineralization of the DCF solutions (conversion to carbon dioxide and water) during the experiments was evaluated by measuring the decay of the TOC concentration using a carbon analyzer (TOC 5000A, Shimadzu). The TOC analysis was always performed immediately after the sample was withdrawn, to avoid further reaction. The TOC concentration includes the carbon content of the target compound, intermediates generated during the experiments, citrate and also organic matter (in the case of STP effluent). The effluent samples were filtered through $0.45 \mu \mathrm{m}$ membranes prior to analysis, so that only the dissolved organic carbon (DOC) was determined.

During degradation of DCF, the residual hydrogen peroxide remaining was measured by the spectrophotometric method employing ammonium metavanadate, using a Shimadzu mini-1240 UV spectrophotometer, as described by Nogueira et al. ${ }^{29}$

\section{Results and Discussion}

\section{Influence of $\mathrm{pH}$}

The low $\mathrm{pH}$ necessary for the photo-Fenton process (2.5-3.0) is a disadvantage for its application in effluent treatment, since neutralization steps are required before to discharge into the environment. The use of in situ generated ferric citrate complex was previously reported by Silva et al. ${ }^{27}$ for the degradation of the herbicide tebuthiuron, where although the degradation efficiency of the iron citrate complex decreased as the $\mathrm{pH}$ increased, tebuthiuron oxidation at $\mathrm{pH} 6$ was higher than that observed in the presence of $\mathrm{Fe}\left(\mathrm{NO}_{3}\right)_{3}$ at $\mathrm{pH} 2.5$.

In the particular case of DCF degradation, the $\mathrm{pH}$ limitation is critical, because above $\mathrm{pH} 3.0$ the iron precipitates, and at $\mathrm{pH} 2.8 \mathrm{DCF}$ presents very low solubility $\left(\mathrm{pK}_{\mathrm{a}}=4.15\right)$. Thus, the use of an iron complex soluble over a wide $\mathrm{pH}$ range, which promotes an efficient degradation, is especially interesting for the degradation of DCF. Therefore, the degradation of DCF was evaluated at four different $\mathrm{pH}$ values (5, 6, 7 and 8), using $\mathrm{FecitNH}_{4}$ as the source of iron for the photo-Fenton process. The experiments were carried out using $0.2 \mathrm{mmol} \mathrm{L}^{-1} \mathrm{FecitNH}_{4}$ and $68 \mathrm{mg} \mathrm{L}^{-1}$ $\mathrm{H}_{2} \mathrm{O}_{2}$. It was observed that the initial $\mathrm{pH}$ strongly affected DCF oxidation and mineralization (Figure 1). Although the oxidation efficiency decreased with increase of $\mathrm{pH}$, the DCF 
concentration was below the detection limit after only $10 \mathrm{~min}$ at $\mathrm{pH} 5$, while after the same time, $77 \%$ and $62 \%$ of oxidation were obtained at pH 6 and 7, respectively (Figure 1A). At $\mathrm{pH} 8$, the degradation was strongly hindered, achieving only $10 \%$ removal after $10 \mathrm{~min}$. This result was even lower than the direct photolysis of DCF ( $\mathrm{pH} 4.2$ ), which caused $35 \%$ degradation after 15 min solar irradiation.
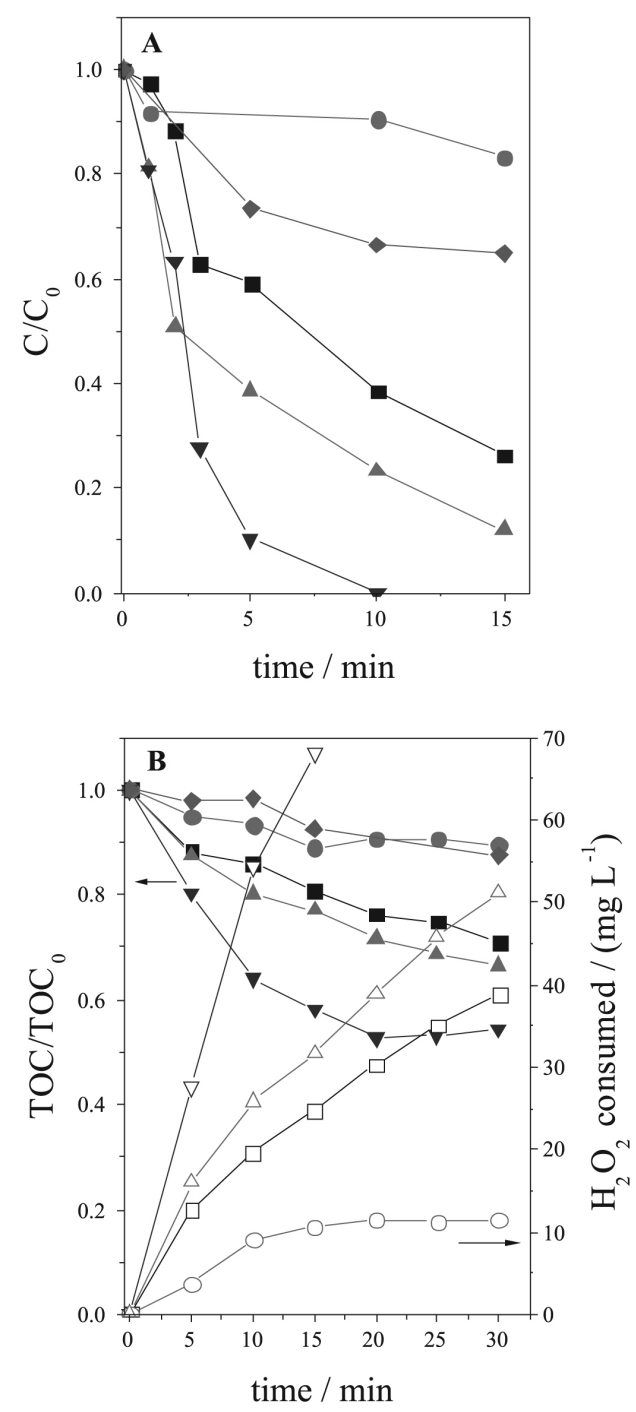

Figure 1. Influence of $\mathrm{pH}$ on (A) DCF oxidation, (B) TOC decay (solid symbols) and $\mathrm{H}_{2} \mathrm{O}_{2}$ consumption (open symbols) during the photo-Fenton process under solar irradiation in distilled water. Initial conditions: $[\mathrm{DCF}]=33.4 \mathrm{mg} \mathrm{L}^{-1}\left(\mathrm{TOC}=16.8 \mathrm{mg} \mathrm{C} \mathrm{L}^{-1}\right) ;\left[\mathrm{FecitNH}_{4}\right]=0.2 \mathrm{mmol} \mathrm{L}^{-1}$; $\left[\mathrm{H}_{2} \mathrm{O}_{2}\right]=68 \mathrm{mg} \mathrm{L}^{-1} \cdot \boldsymbol{\nabla} \mathrm{pH}=5 ; \boldsymbol{\Delta} \mathrm{pH}=6 ; \boldsymbol{\nabla} \mathrm{pH}=7 ; \bullet \mathrm{pH}=8 ; \bullet$ photolysis of DCF $(\mathrm{pH}=4.2)$.

Although, in addition to the DCF carbon content, the TOC concentration includes intermediates generated and the carbon content of citrate, it can be estimated that most of the TOC removal was due to the mineralization of DCF and its intermediates, since only $8 \%$ of TOC was removed due to the photolysis of citrate $\left(0.2 \mathrm{mmol} \mathrm{L}^{-1} \mathrm{FecitNH}_{4}\right.$ at
$\mathrm{pH}$ 6) in a control experiment in the absence of DCF and $\mathrm{H}_{2} \mathrm{O}_{2}$, after 30 min solar irradiation (data not shown).

The initial $\mathrm{pH}$ had similar effect on the TOC removal as observed in the DCF degradation (Figure 1B). The highest mineralization was obtained at initial $\mathrm{pH} 5$, achieving almost $50 \%$ after $20 \mathrm{~min}$ of solar irradiation, during which a plateau was achieved due to the total consumption of $\mathrm{H}_{2} \mathrm{O}_{2}$. At $\mathrm{pH} 6,7$ and 8, 29\%, 24\% and $10 \%$ of the TOC was removed, respectively (Figure $1 \mathrm{~B}$ ). As the $\mathrm{pH}$ increases, the predominant species is $\mathrm{Fe}(\mathrm{OH})(\mathrm{cit})^{-}$, which exhibits lower photoactivity and quantum yield of Fe(II) generation, ${ }^{24,26,30,31}$ consuming less $\mathrm{H}_{2} \mathrm{O}_{2}$, with a lower generation of hydroxyl radicals and consequently, a lower DCF degradation efficiency (Figure 1B).

\section{Influence of FecitNH $\mathrm{H}_{4}$ and $\mathrm{H}_{2} \mathrm{O}_{2}$ concentrations}

The photo-Fenton process at $\mathrm{pH} 7$ is advantageous for the treatment of effluents, avoiding the need for $\mathrm{pH}$ adjustment before either discharge into the environment, or prior to biological treatment, where necessary. Considering that reasonable degradation was achieved at this $\mathrm{pH}$, the next experiments were carried out at $\mathrm{pH} 7$.

DCF degradation was performed using three different FecitNH $_{4}$ concentrations $\left(0.05,0.1\right.$ and $\left.0.2 \mathrm{mmol} \mathrm{L}^{-1}\right)$, and the initial $\mathrm{H}_{2} \mathrm{O}_{2}$ concentration was $68 \mathrm{mg} \mathrm{L}^{-1}$. As illustrated in Figure 2A, the degradation of DCF follows a pseudofirst-order kinetics for all FecitNH $\mathrm{N}_{4}$ concentrations. The rate constants of DCF degradation increase linearly with the increment of $\mathrm{FecitNH}_{4}$ concentration, as shown in Table 2.

The same behaviour was observed for TOC removal. Increase of the $\mathrm{FecitNH}_{4}$ concentration improved mineralization and $\mathrm{H}_{2} \mathrm{O}_{2}$ consumption (Figure 2B). When $0.2 \mathrm{mmol} \mathrm{L}^{-1} \mathrm{FecitNH}_{4}$ was employed, almost $35 \%$ TOC removal was achieved and $39 \mathrm{mg} \mathrm{L}^{-1}$ of hydrogen peroxide was consumed. In contrast, $22 \%$ of TOC removal and $18 \mathrm{mg} \mathrm{L}^{-1}$ of $\mathrm{H}_{2} \mathrm{O}_{2}$ consumption was obtained when $0.1 \mathrm{mmol} \mathrm{L}^{-1}$ of $\mathrm{FecitNH}_{4}$ was used. Only $10 \%$ mineralization and $5 \mathrm{mg} \mathrm{L}^{-1}$ of $\mathrm{H}_{2} \mathrm{O}_{2}$ consumption were observed when the $\mathrm{FecitNH}_{4}$ concentration was reduced to $0.05 \mathrm{mmol} \mathrm{L}^{-1}$ (Figure $2 \mathrm{~B}$ ).

The influence of the initial $\mathrm{H}_{2} \mathrm{O}_{2}$ concentration on DCF degradation was evaluated in the presence of $0.2 \mathrm{mmol} \mathrm{L}^{-1}$ $\mathrm{FecitNH}_{4}$ at $\mathrm{pH}$ 7. A pseudo-first-order kinetics for DCF degradation for all $\mathrm{H}_{2} \mathrm{O}_{2}$ concentrations was also observed (Figure 3A). The rate of DCF decay was enhanced due to the increment of $\mathrm{H}_{2} \mathrm{O}_{2}$ concentration from 34 to $68 \mathrm{mg} \mathrm{L}^{-1}$, resulting in an increase (2.6 fold) of the kinetic constants for the degradation of DCF, and a reduction of the half-life time from 21 to $8 \mathrm{~min}$ (Table 2). However, further increase of $\mathrm{H}_{2} \mathrm{O}_{2}$ concentration ( $68 \mathrm{mg} \mathrm{L}^{-1}$ to $170 \mathrm{mg} \mathrm{L}^{-1}$ ) improved 
only slightly the degradation, reducing the DCF half-life time from 8 to $7.5 \mathrm{~min}$.

Considering TOC removal (Figure 3B), increase of the initial $\mathrm{H}_{2} \mathrm{O}_{2}$ concentration from 34 to $68 \mathrm{mg} \mathrm{L}^{-1}$
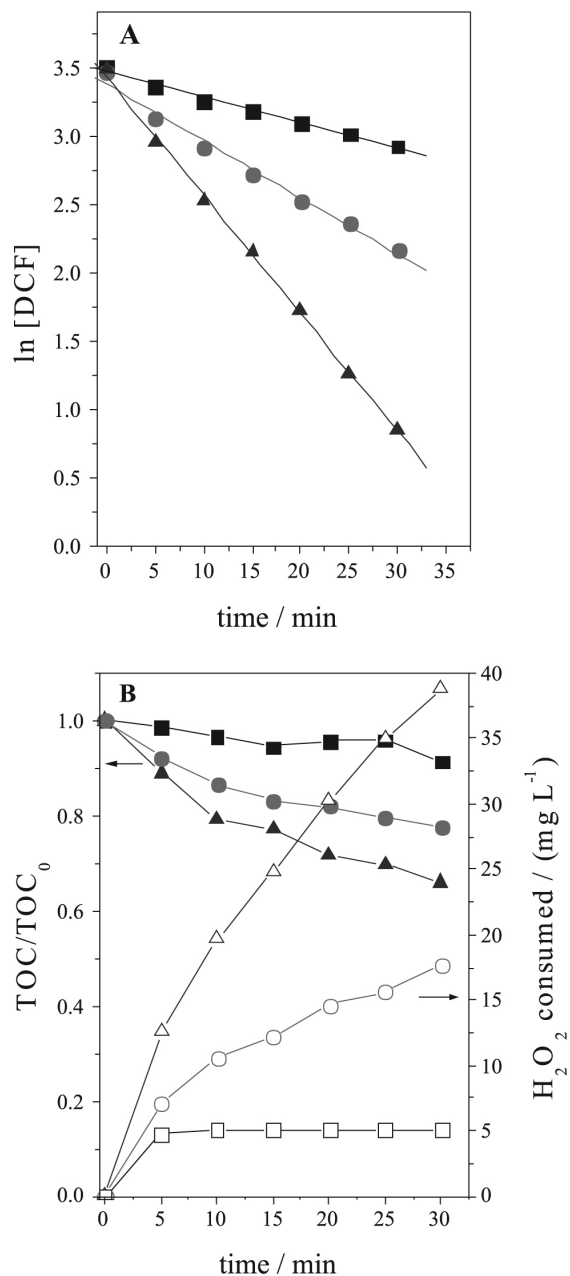

Figure 2. Influence of $\mathrm{FecitNH}_{4}$ concentration on (A) DCF abatement kinetics, (B) TOC decay (solid symbols) and $\mathrm{H}_{2} \mathrm{O}_{2}$ consumption (open symbols), during the photo-Fenton process under solar irradiation in distilled water. Initial conditions: $[\mathrm{DCF}]=33.4 \mathrm{mg} \mathrm{L}^{-1}$ $\left(\mathrm{TOC}=16.8 \mathrm{mg} \mathrm{C} \mathrm{L}^{-1}\right) ;\left[\mathrm{H}_{2} \mathrm{O}_{2}\right]=68 \mathrm{mg} \mathrm{L}^{-1} ; \mathrm{pH}=7$. $0.05 \mathrm{mmol} \mathrm{L}^{-1}$;

- $0.1 \mathrm{mmol} \mathrm{L}^{-1} ; \boldsymbol{\wedge} 0.2 \mathrm{mmol} \mathrm{L}^{-1} \mathrm{FecitNH}_{4}$. resulted in an increase of mineralization from $14 \%$ to $30 \%$ after $30 \mathrm{~min}$ of solar irradiation. However, no improvement was observed with further increase to $170 \mathrm{mg} \mathrm{L}^{-1}$, probably due to a self-decomposition
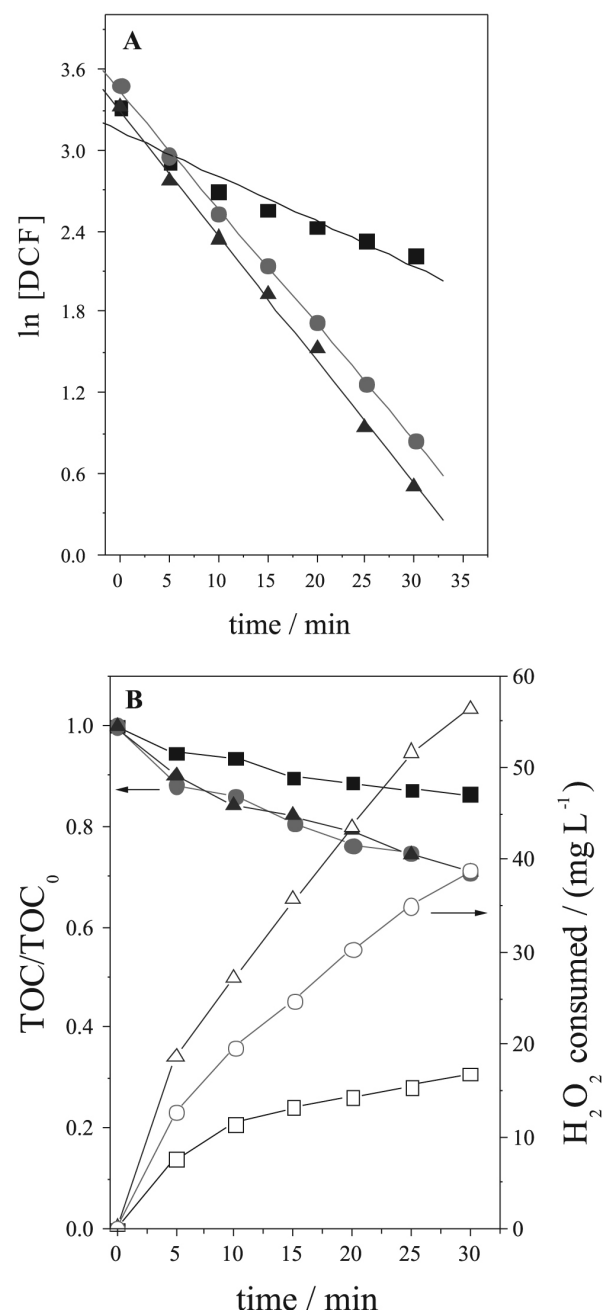

Figure 3. Influence of $\mathrm{H}_{2} \mathrm{O}_{2}$ concentration on (A) DCF abatement kinetics, (B) TOC decay (solid symbols) and $\mathrm{H}_{2} \mathrm{O}_{2}$ consumption (open symbols), during the photo-Fenton process under solar irradiation in distilled water. Initial conditions: $[\mathrm{DCF}]=33.4 \mathrm{mg} \mathrm{L}^{-1}\left(\mathrm{TOC}=16.8 \mathrm{mg} \mathrm{CL}^{-1}\right) ;\left[\mathrm{FecitNH}_{4}\right]=$ $0.2 \mathrm{mmol} \mathrm{L}{ }^{-1} ; \mathrm{pH}=7$. $34 \mathrm{mg} \mathrm{L}^{-1} ; \bullet 68 \mathrm{mg} \mathrm{L}^{-1} ; \boldsymbol{\wedge} 170 \mathrm{mg} \mathrm{L}^{-1} \mathrm{H}_{2} \mathrm{O}_{2}$.

Table 2. Kinetic parameters obtained for DCF degradation under different experimental conditions

\begin{tabular}{|c|c|c|c|c|c|c|}
\hline Matrix & $\mathrm{pH}$ & $\begin{array}{c}{\left[\mathrm{FecitNH}_{4}\right] /} \\
\left(\mathrm{mmol} \mathrm{L}^{-1}\right)\end{array}$ & $\begin{array}{l}{\left[\mathrm{H}_{2} \mathrm{O}_{2}\right] /} \\
\left(\mathrm{mg} \mathrm{L}^{-1}\right)\end{array}$ & $\mathrm{k} / \min ^{-1}$ & $\mathrm{t}_{1 / 2} / \min$ & $\mathrm{r}$ \\
\hline $\mathrm{DW}^{\mathrm{a}}$ & 7 & 0.05 & 68 & 0.0185 & 37 & 0.994 \\
\hline $\mathrm{DW}^{\mathrm{a}}$ & 7 & 0.1 & 68 & 0.0416 & 17 & 0.994 \\
\hline $\mathrm{DW}^{\mathrm{a}}$ & 7 & 0.2 & 68 & 0.0864 & 8.0 & 0.999 \\
\hline $\mathrm{DW}^{\mathrm{a}}$ & 7 & 0.2 & 34 & 0.0336 & 21 & 0.963 \\
\hline $\mathrm{DW}^{\mathrm{a}}$ & 7 & 0.2 & 170 & 0.0922 & 7.5 & 0.999 \\
\hline $\mathrm{STP}^{\mathrm{b}}$ & 7 & 0.2 & 68 & 0.0104 & 67 & 0.965 \\
\hline $\mathrm{STP}^{\mathrm{b}}$ & 5 & 0.2 & 68 & 0.0715 & 9.7 & 0.979 \\
\hline
\end{tabular}

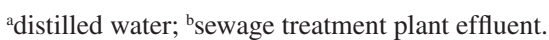


reaction (equation 1) and scavenging of hydroxyl radicals by excess $\mathrm{H}_{2} \mathrm{O}_{2}$ (equation 2). ${ }^{32}$

$$
\begin{aligned}
& \mathrm{H}_{2} \mathrm{O}_{2}+\mathrm{H}_{2} \mathrm{O}_{2} \rightarrow 2 \mathrm{H}_{2} \mathrm{O}+\mathrm{O}_{2} \\
& \mathrm{H}_{2} \mathrm{O}_{2}+\mathrm{HO}^{\circ} \rightarrow \mathrm{H}_{2} \mathrm{O}+\mathrm{HO}_{2}
\end{aligned}
$$

\section{Solar/photo-Fenton degradation of DCF in STP effluent}

Since DCF is a commonly used anti-inflammatory that is often detected in STP effluents, at concentrations ranging from ng L $\mathrm{L}^{-1}$ to $\mu \mathrm{g} \mathrm{L}^{-1,33,34}$ its degradation in this type of medium was studied in order to evaluate matrix effects on the photo-Fenton process efficiency.

The experiment carried out in DW, using $0.2 \mathrm{mmol} \mathrm{L}^{-1}$ $\mathrm{FecitNH}_{4}, 68 \mathrm{mg} \mathrm{L}^{-1} \mathrm{H}_{2} \mathrm{O}_{2}$ (with further additions) and $\mathrm{pH} 7$ (without further $\mathrm{pH}$ adjustment) resulted in total degradation of DCF after 45 min (Figure 4A), while a plateau around $75 \%$ of TOC removal was achieved after 90 min irradiation due to iron precipitation (Figure 4B). This is probably due to $\mathrm{FecitNH}_{4}$ degradation and the formation of hydroxoiron species, hindering further photo-Fenton reaction. The initial $\mathrm{pH}$ decreased from 7 to 5.5 after $5 \mathrm{~min}$. No further $\mathrm{pH}$ decrease was observed up to $150 \mathrm{~min}$ of irradiation. Although iron precipitation occurred, mineralization and $\mathrm{H}_{2} \mathrm{O}_{2}$ consumption was observed at a lower rate after $90 \mathrm{~min}$ irradiation. Therefore a new experiment, with adjustment of $\mathrm{pH}$ to 2.5 after 90 min irradiation, was carried out using the same concentrations of $\mathrm{FecitNH}_{4}$ and $\mathrm{H}_{2} \mathrm{O}_{2}$. The $\mathrm{pH}$ was adjusted to 2.5 only after $90 \mathrm{~min}$, when the concentration of DCF was below the detection limit. As illustrated in Figure 4B, there was an improvement in TOC removal and an increase in $\mathrm{H}_{2} \mathrm{O}_{2}$ consumption, achieving almost total mineralization after 150 min irradiation. In the case of STP effluent, a slow decrease of TOC was observed in the first $45 \mathrm{~min}$, especially at $\mathrm{pH}$ 7. A sharp decrease was then observed, achieving a plateau after $120 \mathrm{~min}$, with residual TOC concentrations of $17 \mathrm{mg} \mathrm{L}^{-1}$ at $\mathrm{pH} 5$ and $22 \mathrm{mg} \mathrm{L}^{-1}$ at $\mathrm{pH} 7$.

In the presence of STP effluent at $\mathrm{pH} 7$, only $38 \%$ DCF oxidation was achieved after $45 \mathrm{~min}$ (Figure 4A), corresponding to a half-life time of $67 \mathrm{~min}, 8.4$ times longer than when present in distilled water (Table 2). The significant effect of STP effluent on DCF oxidation could be due to the presence of organic matter, which competes for hydroxyl radicals, as well as inorganic carbon (carbonate), a hydroxyl radical scavenger (equations 3 and 4):

$$
\begin{aligned}
& \mathrm{HO}^{\bullet}+\mathrm{HCO}_{3}^{-} \rightarrow \mathrm{H}_{2} \mathrm{O}+\mathrm{CO}_{3}^{-} \\
& \mathrm{HO}{ }^{-}+\mathrm{CO}_{3}{ }^{2-} \rightarrow \mathrm{HO}^{-}+\mathrm{CO}_{3}^{-{ }^{-}}
\end{aligned}
$$

Decreased pharmaceutical degradation efficiency in simulated fresh water containing a high carbonate
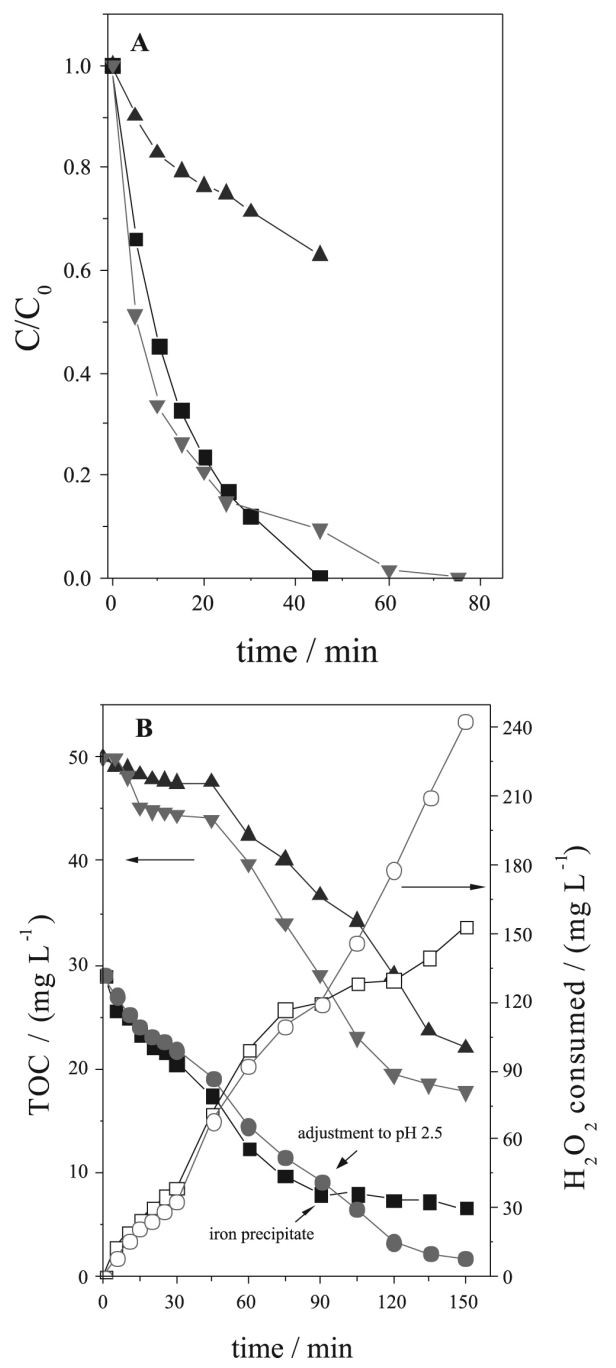

Figure 4. (A) Abatement of DCF concentration (solid symbols) in DW and in STP effluent, (B) TOC removal (solid symbols) and $\mathrm{H}_{2} \mathrm{O}_{2}$ consumption (open symbols), during photo-Fenton process under solar irradiation. Initial conditions: $[\mathrm{DCF}]=33.4 \mathrm{mg} \mathrm{L}^{-1}\left(\mathrm{TOC}=16.8 \mathrm{mg} \mathrm{CL}^{-1}\right)$; $\left[\mathrm{FecitNH}_{4}\right]=0.2 \mathrm{mmolL}^{-1} ;\left[\mathrm{H}_{2} \mathrm{O}_{2}\right]=68 \mathrm{mgL}^{-1}$ (withnew additions). $\mathbf{\Delta} \mathrm{STPpH} 7$; $\checkmark \mathrm{STP}$ pH 5; - DW pH 7 without further $\mathrm{pH}$ adjustment; $\bullet \mathrm{DW} \mathrm{pH} 7$ with $\mathrm{pH}$ adjustment to $\mathrm{pH} 2.5$ after 90 min irradiation. $\mathrm{DW}=$ distilled water and STP = sewage treatment plant effluent.

concentration has been reported in a recent study ${ }^{35}$ where high amounts of iron were needed to improve the efficiency.

In the present study, another experiment was carried out after adjusting the STP effluent $\mathrm{pH}$ to 5 , in order to evaluate the effect of carbonate species on the overall efficiency of the process. At this $\mathrm{pH}$, the concentration of inorganic carbon decreased from $60 \mathrm{mg} \mathrm{C} \mathrm{L}^{-1}$ to $3 \mathrm{mg} \mathrm{C} \mathrm{L}^{-1}$ after stirring overnight. The concentration of DCF was below the detection limit in STP effluent after 75 min irradiation (Figure 4A), demonstrating the interference of carbonate species due to the scavenging of hydroxyl radicals generated during the photo-Fenton process, reducing the efficiency of the degradation. 
Comparing the results obtained in the present work with previous results where ferric sulfate was employed as the iron source (at pHs 2.8, 4 and 7), ${ }^{20}$ a higher degradation rate was obtained in the presence of $\mathrm{FecitNH}_{4}$ complex, with a lower $\mathrm{H}_{2} \mathrm{O}_{2}$ concentration necessary for the total degradation of DCF.

\section{Conclusions}

The use of $\mathrm{FecitNH}_{4}$ complex in the photo-Fenton degradation of DCF under solar irradiation allowed the process to be carried out at $\mathrm{pH}$ values between 5 and 7 . Although increase of the initial $\mathrm{pH}$ significantly decreased the degradation efficiency, the DCF concentration was below of the detection limit and 62\% DCF oxidation were achieved at $\mathrm{pH}$ values between 5 and 7 after only 10 min irradiation. Significant mineralization demanded longer reaction times, as $77 \%$ TOC was removed after 150 min irradiation at $\mathrm{pH} 7$, using $0.2 \mathrm{mmol} \mathrm{L}^{-1} \mathrm{FecitNH}_{4}$ and $68 \mathrm{mg} \mathrm{L}^{-1} \mathrm{H}_{2} \mathrm{O}_{2}$. Further increase of the $\mathrm{H}_{2} \mathrm{O}_{2}$ concentration to $170 \mathrm{mg} \mathrm{L}^{-1}$ only slightly improved the DCF oxidation. When present in STP effluent at $\mathrm{pH} 7$, the degradation of DCF was strongly affected by the high concentration of inorganic carbon, confirmed by the improvement of degradation after elimination of carbonates.

\section{Acknowledgments}

The authors thank FAPESP (05/00172-0) for the scholarship awarded to A.G. Trovó and CNPq (471283/2007-0) for the financial support of this work.

\section{References}

1. Hernando, M.D.; Mezcua, M.; Fernández-Alba,A. R.; Barceló, D.; Talanta 2006, 69, 334.

2. Quinn, B.; Gagné, F.; Blaise, C. ; Sci. Total Environ. 2008, 389, 306.

3. Conkle, J. L.; White, J. R.; Metcalfe, C. D.; Chemosphere 2008, $73,1741$.

4. Ternes, T. A.; Water Res. 1998, 32, 3245.

5. Stumpf, M.; Ternes, T. A.; Wilken, R. D.; Rodrigues, S. V.; Baumann, W.; Sci. Total Environ. 1999, 225, 135.

6. Gros, M.; Petrovic, M.; Barceló, D.; Talanta 2006, 70, 678.

7. Zuccato, E.; Castiglioni, S.; Fanelli, R.; J. Hazard. Mat. 2005, 122, 205.

8. Lindqvist, N.; Tuhkanen, T.; Kronberg, L.; Water Res. 2005 , 39, 2219.

9. http://biq.iqm.unicamp.br/arquivos/teses/vtls000398476.pdf accessed in December 2008.

10. Lishman, L.; Smyth, S. A.; Sarafin, K.; Kleywegt, S.; Toito, J.; Peart, T.; Lee, B.; Servos, M.; Beland, M.; Seto, P.; Sci. Total Environ. 2006, 367, 554.
11. Gómez, M. J.; Bueno, M. J. M.; Lacorte, S.; Fernández-Alba, A. R.; Agüera, A.; Chemosphere 2007, 66, 993.

12. Seiler, J. P.; Toxicol. Lett. 2002, 131, 105.

13. Nogueira, R. F. P.; Trovó, A. G.; Silva, M. R. A.; Villa, R. D.; Quim. Nova 2007, 30, 400.

14. Trovó, A. G.; Melo, S. A.; Nogueira, R. F. P.; J. Photochem. Photobiol. A 2008, 198, 215.

15. Trovó, A. G.; Nogueira, R. F. P.; Aguera, A.; Fernandez-Alba, A. R.; Sirtori, C.; Malato, S.; Water Res. 2009, 43, 3922.

16. Buser, H-R.; Poiger, T.; Müller, M. D.; Environ. Sci. Technol. 1998, 32, 3449.

17. Vogna,D.; Marotta, R.;Napolitano,A.;Andreozzi, R.; d'Ischia, M.; Water Res. 2004, 38, 414.

18. Kim, I.; Tanaka, H.; Environ. Int. 2009, 35, 793.

19. Coelho, A. D.; Sans, C.; Aguera, A.; Gómez, M. J.; Esplugas, S.; Dezotti, M.; Sci. Total Environ. 2009, 407, 3572.

20. Pérez-Estrada, L. A.; Maldonado, M. I.; Gernjak, W.; Agüera, A.; Fernández-Alba, A. R.; Ballesteros, M. M.; Malato, S.; Catal. Today 2005, 101, 219.

21. Nogueira, R. F. P.; Silva, M. R. A.; Trovó, A. G.; Sol. Energy 2005, 79, 384.

22. Sun, Y.; Pignatello, J. J.; J. Agric. Food Chem. 1992, 40, 322.

23. Sillanpaa, M.; Pirkanniemi, K.; Environ. Tecnhol. 2001, 22, 791.

24. Abrahamson, H. B.; Rezvani, A. B.; Brushmiller, J. G.; Inorg. Chim. Acta 1994, 226, 117.

25. Zepp, R. G.; Faust, B. C.; Hoigné, J. ; Environ. Sci. Technol. 1992, 26, 313.

26. Nansheng, D.; Feng, W.; Fan, L.; Mei, X.; Chemosphere 1998 , 36, 3101 .

27. Silva, M. R. A.; Trovó, A. G.; Nogueira, R. F. P.; J. Photochem. Photobiol., A 2007, 191, 187.

28. Sun, Y.; Pignatello, J. J.; J. Agric. Food Chem. 1993, 41, 308.

29. Nogueira, R. F. P.; Oliveira, M. C.; Paterlini, W. C.; Talanta 2005, 66, 86 .

30. Hug, S. J.; Canonica, L.; Wegelin, M.; Gechter, D.; Guntn, U. V.; Environ. Sci. Technol. 2001, 35, 2114.

31. Faust, B. C.; Zepp, R. G.; Environ. Sci. Technol. 1993, $27,2517$.

32. Parra, S.; Sarria, V.; Malato, S.; Péringer, P.; Pulgarin, C.; Appl. Catal., B 2000, 27, 153.

33. Kim, S. D.; Cho, J.; Kim, I. S.; Vanderford, B. J.; Snyder, S. A.; Water Res. 2007, 41, 1013.

34. Stulten, D.; Zühlke, S.; Lamshöft, M.; Spiteller, M.; Sci. Total Environ. 2008, 405, 310.

35. Klamerth, N.; Miranda, N.; Malato, S.; Agüera, A.; FernándezAlba, A. R.; Maldonado, M. I.; Coronado, J. M.; Catal. Today 2009, 144, 124.

Submitted: May 19, 2010

Published online: February 10, 2011

FAPESP has sponsored the publication of this article. 